\title{
One-Pot Synthesis of Hypervalent Diaryl(iodo)bismuthanes from o-Carbonyl Iodoarenes by Zincation
}

\author{
Toshihiro Murafuji $\left(\mathbb{D},{ }^{1,2}\right.$ A. F. M. Hafizur Rahman, ${ }^{2}$ Daiki Magarifuchi, ${ }^{3}$ Masahiro Narita, ${ }^{1}$ \\ Isamu Miyakawa, ${ }^{1,3}$ Katsuya Ishiguro, ${ }^{1,3}$ and Shin Kamijo ${ }^{1,3}$ \\ ${ }^{1}$ Graduate School of Sciences and Technology for Innovation, Yamaguchi University, Yamaguchi 753-8512, Japan \\ ${ }^{2}$ Graduate School of Medicine, Yamaguchi University, Yamaguchi 753-8512, Japan \\ ${ }^{3}$ Graduate School of Science and Engineering, Yamaguchi University, Yamaguchi 753-8512, Japan \\ Correspondence should be addressed to Toshihiro Murafuji; murafuji@yamaguchi-u.ac.jp
}

Received 31 October 2018; Accepted 22 January 2019; Published 27 February 2019

Academic Editor: Oscar Navarro

Copyright (C) 2019 Toshihiro Murafuji et al. This is an open access article distributed under the Creative Commons Attribution License, which permits unrestricted use, distribution, and reproduction in any medium, provided the original work is properly cited.

Diaryl(iodo)bismuthanes possessing a hypervalent $\mathrm{C}=\mathrm{O} \bullet \bullet \cdot \mathrm{Bi}-\mathrm{I}$ bond were conveniently synthesized in a one-pot reaction by using arylzinc reagents generated from $o$-carbonyl iodobenzenes and zinc powder under ultrasonication. This method is superior to the conventional organolithium and Grignard methods because it has a wide functional group tolerance, requires no protecting group manipulations, and proceeds under mild reaction conditions that do not need low temperature control. Furthermore, no intermediate triarylbismuthane precursor for the hypervalent iodobismuthane is necessary.

\section{Introduction}

Much effort has been devoted to the study of hypervalent bismuth(III) compounds [1-5]. Hypervalent bonds are formed efficiently via intramolecular coordination of a neutral donor to a bismuth(III) center [6-12]. We have used this method to synthesize various hypervalent organobismuth(III) compounds stabilized by intramolecular coordination and have characterized their molecular structures [13]. Furthermore, we have revealed that these compounds show antifungal activities against the yeast Saccharomyces cerevisiae $[14,15]$. In particular, compounds $\mathbf{1}$ and $\mathbf{2}$, which possess diary sulfone and acetophenone molecular scaffold, respectively, exhibited high antifungal activities.

These compounds are synthesized by directed ortholithiation (Scheme 1). Directed lithiation is a very useful and reliable synthetic method for introducing a molecular scaffold bearing an ortho-coordinative functional group, although the method can suffer from various practical difficulties. For example, the synthesis of $\mathbf{1}$ and $\mathbf{2}$ used triarylbismuthane as a precursor because the ortho-functionalized aryllithiums were too reactive to give $\mathbf{1}$ and $\mathbf{2}$ directly through their reactions with $\mathrm{BiI}_{3}$ and $\mathrm{ArBiX}_{2}$, respectively. Furthermore, the acetyl substituent of acetophenone is incompatible with BuLi, meaning that the synthesis of $\mathbf{2}$ started from the protected silyl enol ether, and the harsh reaction conditions requiring excess $\mathrm{BuLi}$ caused the loss of $\mathrm{Ar}_{2} \mathrm{BiCl}$ or the decomposition of the product, lowering the reproducibility of the yield $[13,14]$. To facilitate the search for active antifungal compounds, a general and convenient synthetic method that has wide functional group compatibility for introducing various molecular scaffolds to the bismuth(III) center is required.

We have reported the synthesis under Grignard conditions of $p$-substituted triarylbismuthanes $\mathbf{3}$ and $\mathbf{4}$, which have a formyl and ester substituent, respectively (Scheme 2) [16]. The imino and ester substituents were tolerated despite their polarized double bond, although 3 required protection of the formyl substituent and $\mathbf{4}$ needed low-temperature control. Based on these results, we investigated using a type of organometallic reagent that is less reactive than Grignard reagents. Such an organometallic reagent would be compatible with carbonyl functional group and thus a suitable synthetic tool for use in our desired general method. 


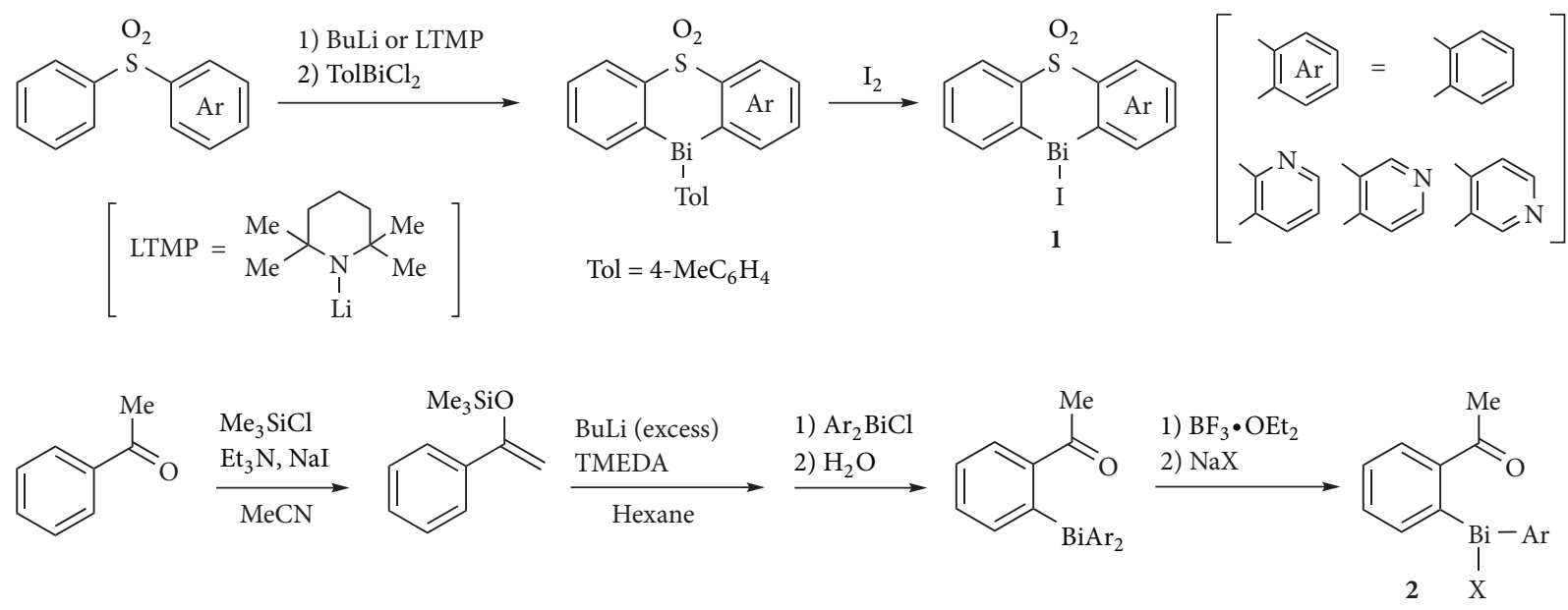

SCHEME 1: Synthesis of $\mathbf{1}$ and $\mathbf{2}$ by directed lithiation.

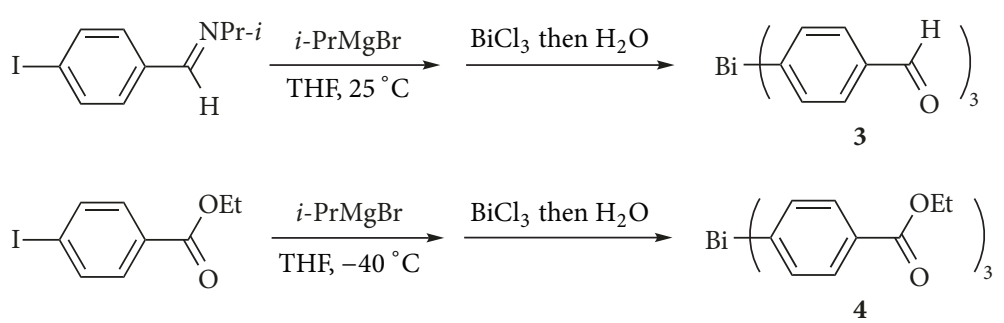

Scheme 2: Synthesis of 3 and 4.

Several mild bismuth-carbon bond forming reactions have been reported, which include the treatment of aryl iodides with bismuth shot in the presence of $\mathrm{Cu}$ and $\mathrm{CuI}$ by ball milling [17], the arylation of bismuth(III) carboxylates by sodium tetraarylborate [18], and the reaction of $\mathrm{BiCl}_{3}$ with organozinc reagents [19]. To achieve wide functional group tolerance, we chose organozinc reagents because they are compatible with carbonyl functionalities such as ester, acetyl, and even formyl substituents, and the chemistry of these reagents is well established [20-22]. Herein, we report the synthesis of hypervalent iodobismuthanes $\mathbf{2 a}$ and 5a-10a, which contain a carbonyl group, by zincation of the corresponding iodoarenes (Scheme 3). The organozinc method was superior to our previously reported organolithium and Grignard methods owing to the high functional group tolerance, short synthesis, mild reaction conditions, and acceptable yields.

\section{Materials and Methods}

All of the reactions were carried out under argon unless otherwise noted. N,N-Dimethylformamide (DMF) was distilled from calcium hydride under reduced pressure. 1,4Dioxane was distilled from calcium hydride. Diethyl ether was distilled from benzophenone ketyl before use. ${ }^{1} \mathrm{H}$ and ${ }^{13} \mathrm{C} \mathrm{NMR}$ spectra were recorded in $\mathrm{CDCl}_{3}$ or DMSO$d_{6}$ on a BRUKER AVANCE 400 S spectrometer. Chemical shifts were referenced to residual solvent peak: chloroform
(7.26 ppm, $77.0 \mathrm{ppm}$ ) and DMSO (2.50 ppm, $40.45 \mathrm{ppm}$ ). IR spectra were obtained as $\mathrm{KBr}$ pellets on a Nicolet FT-IR Impact 410 spectrophotometer. Melting points were determined on a YANAGIMOTO melting point apparatus without correction. Elemental analysis was performed on a MICRO CORDER JM10 apparatus (J-SCIENCE LAB. Co.). HRMS were recorded on a Bruker Daltonics micrOTOF II (APCI) instrument. 2 '-Iodoacetophenone and ethyl 2 -iodobenzoate were commercially available. 2Iodobenzaldehyde, 4-fluoro-2-iodobenzaldehyde, 2-iodo-5methoxybenzaldehyde, $4^{\prime}$-fluoro- $2^{\prime}$-iodoacetophenone, and 3-iodothiophene-2-carboxaldehyde were prepared in high yields by Finkelstein reaction of the corresponding bromoarenes in accordance with the literature [23].

2.1. Typical Procedure for the Finkelstein Reaction of Bromoarenes. To a round-bottomed flask $(50 \mathrm{~mL})$ equipped with a magnetic stir bar were added bromoarene $(2.5 \mathrm{mmol})$, $\mathrm{CuI}$ (5 mol\%), NaI (5 mmol), and 1,3-diaminopropane (10 mol\%). After dry 1,4-dioxane $(2.5 \mathrm{~mL})$ was added to the flask, the mixture was refluxed for $24 \mathrm{~h}$. The reaction was quenched with water $(30 \mathrm{~mL})$ at room temperature and the resulting mixture was extracted with ethyl acetate $(3 \times 30$ $\mathrm{mL})$. The organic layer was dried $\left(\mathrm{Na}_{2} \mathrm{SO}_{4}\right)$ and concentrated to leave a residue, which was chromatographed on silica gel with hexane-ethyl acetate (5:1) to give the corresponding iodoarene, which was used in the next step without further purification. 
<smiles>[X]c1ccc(C(C)=O)c(Br)c1</smiles>

2a: $\mathrm{X}=\mathrm{H}$ 5a: $X=F$<smiles>[X]c1ccc(C=O)c([Bi](I)I)c1</smiles>

6a: $\mathrm{X}=\mathrm{H}$ $7 \mathrm{a}: \mathrm{X}=\mathrm{F}$<smiles>COc1ccc(Br)c(C=O)c1</smiles>

$8 \mathrm{a}$<smiles>O=Cc1sccc1[Bi]I</smiles>

9a<smiles>CCOC(=O)c1ccccc1B(Br)Br</smiles>

10a

SCHEme 3: Hypervalent iodobismuthanes functionalized with a carbonyl group.

2.2. 2-Iodobenzaldehyde. Yield $99 \%$ (574 mg, $2.48 \mathrm{mmol}$ ), Colorless solid, mp 39-41 ${ }^{\circ} \mathrm{C} .{ }^{1} \mathrm{H}$ NMR (400 $\mathrm{MHz}, \mathrm{CDCl}_{3}$ ): $\delta 7.29(1 \mathrm{H}, \mathrm{dt}, J=7.6 \mathrm{~Hz}, 1.6 \mathrm{~Hz}), 7.47(1 \mathrm{H}, \mathrm{t}, J=7.6 \mathrm{~Hz}), 7.89$ $(1 \mathrm{H}, \mathrm{dd}, J=7.6 \mathrm{~Hz}, 1.6 \mathrm{~Hz}), 7.96(1 \mathrm{H}, \mathrm{d}, J=8.0 \mathrm{~Hz}), 10.08(1 \mathrm{H}$, s).

2.3. 4-Fluoro-2-Iodobenzaldehyde. Yield 97\% (606 mg, 2.43 mmol), Colorless solid, mp 49-51 ${ }^{\circ} \mathrm{C} .{ }^{1} \mathrm{H}$ NMR $(400 \mathrm{MHz}$, $\left.\mathrm{CDCl}_{3}\right): \delta 7.19(1 \mathrm{H}, \mathrm{m}), 7.68(1 \mathrm{H}, \mathrm{m}), 7.91(1 \mathrm{H}, \mathrm{m}), 9.99(1 \mathrm{H}$, $\mathrm{d}, J=2.4 \mathrm{~Hz})$.

2.4. 2-Iodo-5-Methoxybenzaldehyde. Yield 98\% (642 mg, $2.45 \mathrm{mmol})$, Colorless solid, mp $113-116^{\circ} \mathrm{C} .{ }^{1} \mathrm{H}$ NMR (400 $\left.\mathrm{MHz} \mathrm{CDCl}_{3}\right): \delta 3.84(3 \mathrm{H}, \mathrm{s}), 6.92(1 \mathrm{H}, \mathrm{dd}, J=8.4 \mathrm{~Hz}, 3.2$ $\mathrm{Hz}), 7.43(1 \mathrm{H}, \mathrm{d}, J=3.2 \mathrm{~Hz}), 7.80(1 \mathrm{H}, \mathrm{d}, J=8.4 \mathrm{~Hz}), 10.02(1 \mathrm{H}$, s).

2.5. $4^{\prime}$-Fluoro-2'-Iodoacetophenone. Yield 98\% (647 mg, 2.45 mmol), Colorless solid, mp $45-46{ }^{\circ} \mathrm{C} .{ }^{1} \mathrm{H}$ NMR $(400 \mathrm{MHz}$, $\left.\mathrm{CDCl}_{3}\right): \delta 2.59(3 \mathrm{H}, \mathrm{s}), 7.11(1 \mathrm{H}, \mathrm{m}), 7.52(1 \mathrm{H}, \mathrm{m}), 7.65(1 \mathrm{H}, \mathrm{m})$.

2.6. 3-Iodothiophene-2-Carboxaldehyde. Yield 99\% (589 mg, $2.48 \mathrm{mmol})$, Colorless solid, mp $82-85^{\circ} \mathrm{C}$. ${ }^{1} \mathrm{H}$ NMR (400 $\left.\mathrm{MHz}_{\mathrm{CDCl}}\right): \delta 7.28(1 \mathrm{H}, \mathrm{d}, J=4.8 \mathrm{~Hz}), 7.70(1 \mathrm{H}, \mathrm{dd}, J=4.8$ $\mathrm{Hz}, 1.2 \mathrm{~Hz}), 9.83(1 \mathrm{H}, \mathrm{d}, J=1.2 \mathrm{~Hz})$.

2.7. Typical Procedure for the Synthesis of Aryl(iodo)(4methylphenyl)bismuthane. To a round-bottomed flask (50 mL) equipped with a magnetic stir bar were added bismuth(III) chloride (422 $\mathrm{mg}, 1.33 \mathrm{mmol})$ and tris(4methylphenyl)bismuthane (323 $\mathrm{mg}, 0.67 \mathrm{mmol}$ ). After dry diethyl ether $(6 \mathrm{~mL})$ was added to the flask at room temperature, the mixture was stirred for $1 \mathrm{~h}$. To another round-bottomed flask $(50 \mathrm{~mL})$ were added iodoarene (1 $\mathrm{mmol}$ ), zinc powder (262 $\mathrm{mg}, 4 \mathrm{mmol})$, and dry DMF (5 $\mathrm{mL})$. The flask was set in an ultrasonic water bath at room temperature $\left(25^{\circ} \mathrm{C}\right)$ and the resulting mixture was sonicated for 1.5-4 h, during which time the water bath temperature rose to $48^{\circ} \mathrm{C}$. The sonication was stopped and unreacted zinc powder precipitated. The resulting supernatant solution containing an arylzinc reagent was slowly transferred to the suspension of dichloro(4-methylphenyl)bismuthane (ca. 2 $\mathrm{mmol}$ ) thus formed, and the resulting mixture was stirred for 3.5-8 $\mathrm{h}$ at room temperature. The reaction was quenched with a saturated aqueous solution of $\mathrm{NaI}(3 \mathrm{~mL})$ and the resulting mixture was extracted with ethyl acetate $(3 \times 50$
$\mathrm{mL}$ ). The combined extracts were concentrated to leave an oily residue, which was chromatographed on silica gel with hexane-ethyl acetate (5:1) to afford the corresponding iodobismuthane.

2.8. (2-Acetylphenyl)iodo(4-methylphenyl)bismuthane $2 \boldsymbol{a}$. Yellow crystal, Yield 35\% (191 mg, $0.35 \mathrm{mmol}$ ), mp 160-162 ${ }^{\circ} \mathrm{C}$. ${ }^{1} \mathrm{H} \mathrm{NMR}\left(400 \mathrm{MHz}, \mathrm{CDCl}_{3}\right): \delta 2.25(3 \mathrm{H}, \mathrm{s}), 2.69(3 \mathrm{H}, \mathrm{s})$, $7.25(2 \mathrm{H}, \mathrm{d}, J=8.0 \mathrm{~Hz}), 7.71(1 \mathrm{H}, \mathrm{dt}, J=7.6 \mathrm{~Hz}, 1.2 \mathrm{~Hz}), 7.88$ $(1 \mathrm{H}, \mathrm{dt}, J=7.6 \mathrm{~Hz}, 1.2 \mathrm{~Hz}), 8.07(2 \mathrm{H}, \mathrm{d}, J=8.0 \mathrm{~Hz}), 8.22(1 \mathrm{H}$, $\mathrm{dd}, J=7.6 \mathrm{~Hz}, 1.2 \mathrm{~Hz}), 9.41(1 \mathrm{H}, \mathrm{dd}, J=7.2 \mathrm{~Hz}, 0.8 \mathrm{~Hz}) .{ }^{13} \mathrm{C}$ $\mathrm{NMR}\left(100 \mathrm{MHz}, \mathrm{CDCl}_{3}\right): \delta 21.54,27.08,128.50,132.36,134.51$, 138.01, 138.21, 138.98, 143.10, 145.55, 166.78, 172.09, 207.54. IR (KBr): $v$ 3738, 3037, 1622, 1552, 1276 and $761 \mathrm{~cm}^{-1}$. HRMS (APCI) calcd. for $\mathrm{C}_{15} \mathrm{H}_{13} \mathrm{BiIO}$ : $[\mathrm{M}-\mathrm{H}]^{-}$544.9832. found: 544.9821 .

2.9. (2-Acetyl-5-fluorophenyl)iodo(4-methylphenyl)bismuthane 5a. Yellow crystal, Yield 28\% (158 mg, $0.28 \mathrm{mmol}), \mathrm{mp}$ $186-188^{\circ} \mathrm{C} .{ }^{1} \mathrm{H}$ NMR $\left(400 \mathrm{MHz}, \mathrm{DMSO}-d_{6}\right): \delta 2.19(3 \mathrm{H}, \mathrm{s})$, $2.72(3 \mathrm{H}, \mathrm{s}), 7.29(2 \mathrm{H}, \mathrm{d}, J=7.6 \mathrm{~Hz}), 7.54(1 \mathrm{H}, \mathrm{dt}, J=8.4 \mathrm{~Hz}$, $2.0 \mathrm{~Hz}), 8.11(2 \mathrm{H}, \mathrm{d}, J=7.6 \mathrm{~Hz}), 8.55(1 \mathrm{H}, \mathrm{dd}, J=8.4 \mathrm{~Hz}, 4.8$ $\mathrm{Hz}), 8.89$ (1H, br-s). ${ }^{13} \mathrm{C}$ NMR (100 MHz, DMSO- $\left.d_{6}\right): \delta 21.13$, 27.48, 115.62 (d, $J=22.6 \mathrm{~Hz}), 130.94$ (br-d), 132.08( $\times 2), 137.09$, $138.45,138.85$ (d, $J=8.0 \mathrm{~Hz}), 140.51,169.52,172.12,207.85$. IR (KBr): $v$ 1620, 1575, 1558, 1358, 1299, 1262 and $1201 \mathrm{~cm}^{-1}$. HRMS (APCI) calcd. for $\mathrm{C}_{15} \mathrm{H}_{12}$ BiFIO: $[\mathrm{M}-\mathrm{H}]^{-} 562.9730$. found: 562.9726 .

2.10. (2-Formylphenyl)iodo(4-methylphenyl)bismuthane $\mathbf{6 a}$. Yellow crystal, Yield 56\% (298 mg, $0.56 \mathrm{mmol}), \mathrm{mp}$ $143-144^{\circ} \mathrm{C} .{ }^{1} \mathrm{H}$ NMR $\left(400 \mathrm{MHz}, \mathrm{DMSO}-d_{6}\right): \delta 2.21(3 \mathrm{H}, \mathrm{s})$, $7.30(2 \mathrm{H}, \mathrm{d}, J=7.6 \mathrm{~Hz}), 7.86(1 \mathrm{H}, \mathrm{t}, J=7.2 \mathrm{~Hz}), 7.95(1 \mathrm{H}, \mathrm{t}, J$ $=7.2 \mathrm{~Hz}), 8.14(2 \mathrm{H}, \mathrm{d}, J=7.6 \mathrm{~Hz}), 8.44(1 \mathrm{H}, \mathrm{d}, J=7.2 \mathrm{~Hz})$, $9.02(1 \mathrm{H}, \mathrm{d}, J=7.2 \mathrm{~Hz}), 10.75(1 \mathrm{H}, \mathrm{s}) .{ }^{13} \mathrm{C}$ NMR $(100 \mathrm{MHz}$, $\left.\mathrm{CDCl}_{3}\right): \delta 21.55,128.65,132.47,137.58,138.23,138.44,139.63$, 143.66, 146.16, 165.99, 170.92, 199.50. IR (KBr): v 3058, 2857, 1633, 1572, 1553, 1296 and $1207 \mathrm{~cm}^{-1}$. HRMS (APCI) calcd. for $\mathrm{C}_{14} \mathrm{H}_{13}$ BiIO: $[\mathrm{M}+\mathrm{H}]^{+}$532.9808. found: 532.9810 .

2.11. (2-Formyl-5-fluorophenyl)iodo(4-methylphenyl)bismuthane $7 \boldsymbol{a}$. Yellow crystal, Yield 29\% (195 mg, $0.29 \mathrm{mmol}$ ), mp $148-149^{\circ} \mathrm{C} .{ }^{1} \mathrm{H}$ NMR $\left(400 \mathrm{MHz}, \mathrm{DMSO}-d_{6}\right): \delta 2.21(3 \mathrm{H}, \mathrm{s})$, $7.32(2 \mathrm{H}, \mathrm{d}, J=7.6 \mathrm{~Hz}), 7.61(1 \mathrm{H}, \mathrm{dt}, J=8.4 \mathrm{~Hz}, 2.4 \mathrm{~Hz}), 8.18$ $(2 \mathrm{H}, \mathrm{d}, J=7.6 \mathrm{~Hz}), 8.52(1 \mathrm{H}, \mathrm{dd}, J=8.0 \mathrm{~Hz}, 5.2 \mathrm{~Hz}), 8.74(1 \mathrm{H}$, $\mathrm{d}, J=6.4 \mathrm{~Hz}), 10.74(1 \mathrm{H}, \mathrm{s}) .{ }^{13} \mathrm{C}$ NMR $\left(100 \mathrm{MHz}, \mathrm{DMSO}-d_{6}\right)$ : 


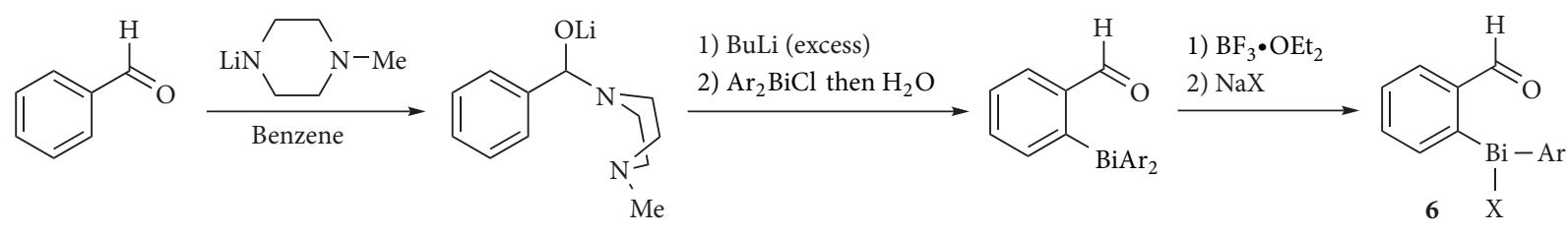

Scheme 4: Conventional synthesis of 6 by directed lithiation.

$\delta 21.14,115.75(\mathrm{~d}, J=22.7 \mathrm{~Hz}), 131.83$ (br-s), 132.17(×2), 137.05, 139.01, 140.73 (d, $J=9.0 \mathrm{~Hz}), 140.88,169.19,171.80,199.67$. IR (KBr): $v$ 3061, 2875, 1638, 1582, 1561, 1259 and $1204 \mathrm{~cm}^{-1}$. HRMS (APCI) calcd. for $\mathrm{C}_{14} \mathrm{H}_{10}$ BiFIO: $[\mathrm{M}-\mathrm{H}]^{-} 548.9566$. found: 548.9570 .

2.12. (2-Formyl-4-methoxyphenyl)iodo(4-methylphenyl)bismuthane 8a. Yellow crystal, Yield $31 \%$ (175 mg, $0.31 \mathrm{mmol}$ ); mp $146-147^{\circ} \mathrm{C} ;{ }^{1} \mathrm{H}$ NMR (400 MHz, DMSO- $\left.d_{6}\right): \delta 2.22(3 \mathrm{H}$, s), $3.87(3 \mathrm{H}, \mathrm{s}), 7.31(2 \mathrm{H}, \mathrm{d}, J=8.0 \mathrm{~Hz}), 7.48(1 \mathrm{H}, \mathrm{dd}, J=7.6$ $\mathrm{Hz}, 2.8 \mathrm{~Hz}), 7.99(1 \mathrm{H}, \mathrm{d}, J=2.8 \mathrm{~Hz}), 8.13(2 \mathrm{H}, \mathrm{d}, J=7.6 \mathrm{~Hz})$, $8.78(1 \mathrm{H}, \mathrm{d}, J=8.0 \mathrm{~Hz}), 10.66(1 \mathrm{H}, \mathrm{s}) .{ }^{13} \mathrm{C} \mathrm{NMR}(100 \mathrm{MHz}$, $\left.\mathrm{CDCl}_{3}\right): \delta 21.57,55.67,122.95,125.69,132.38,138.20,138.31$, $145.09,147.94,160.26,161.34,166.38,199.13$. IR (KBr): v 3027, 2924, 2862, 1640, 1585, 1552, 1460, 1251 and $1044 \mathrm{~cm}^{-1}$. HRMS (APCI) calcd. for $\mathrm{C}_{15} \mathrm{H}_{13} \mathrm{BiIO}_{2}$ : $[\mathrm{M}-\mathrm{H}]^{-}$560.9770. found: 560.9770 .

2.13. (2-Formyl-3-thienyl)iodo(4-methylphenyl)bismuthane 9a. Yellow crystal, Yield 53\% (287 mg, $0.53 \mathrm{mmol}$ ), $\mathrm{mp}$ 132-133 ${ }^{\circ} \mathrm{C} .{ }^{1} \mathrm{H}$ NMR $\left(400 \mathrm{MHz}, \mathrm{CDCl}_{3}\right): \delta 2.28(3 \mathrm{H}, \mathrm{s}), 7.31$ $(2 \mathrm{H}, \mathrm{d}, J=7.6 \mathrm{~Hz}), 8.04(1 \mathrm{H}, \mathrm{d}, J=4.4 \mathrm{~Hz}), 8.09(1 \mathrm{H}, \mathrm{d}, J=$ $4.4 \mathrm{~Hz}), 8.14(2 \mathrm{H}, \mathrm{d}, J=7.6 \mathrm{~Hz}), 10.12(1 \mathrm{H}, \mathrm{s}) .{ }^{13} \mathrm{C}$ NMR $(100$ $\left.\mathrm{MHz}_{\mathrm{CDCl}}\right): \delta 21.58,132.67,138.50,138.56,142.08,145.66$, 148.47, 166.97, 174.32, 186.44. IR (KBr): $v$ 1586, 1483, 1450, 1397, 1337, 1195, 853 and $794 \mathrm{~cm}^{-1}$. HRMS (APCI) calcd. for $\mathrm{C}_{12} \mathrm{H}_{11}$ BiIOS: $[\mathrm{M}+\mathrm{H}]^{+}$538.9374. found: 538.9374 .

2.14. (2-Ethoxycarbonylphenyl)iodo(4-methylphenyl)bismuthane 10a. Yellow crystal, Yield $61 \%$ (351 mg, $0.61 \mathrm{mmol}$ ), mp $125-126^{\circ} \mathrm{C} .{ }^{1} \mathrm{H}$ NMR $\left(400 \mathrm{MHz}, \mathrm{CDCl}_{3}\right): \delta 1.40(3 \mathrm{H}, \mathrm{t}$, $J=7.2 \mathrm{~Hz}), 2.26(3 \mathrm{H}, \mathrm{s}), 4.43(2 \mathrm{H}, \mathrm{m}), 7.26(2 \mathrm{H}, \mathrm{d}, J=7.6$ $\mathrm{Hz}), 7.36(1 \mathrm{H}, \mathrm{dt}, J=7.6 \mathrm{~Hz}, 0.8 \mathrm{~Hz}), 7.84(1 \mathrm{H}, \mathrm{dt}, J=7.6 \mathrm{~Hz}$, $1.2 \mathrm{~Hz}), 8.09(2 \mathrm{H}, \mathrm{d}, J=7.6 \mathrm{~Hz}), 8.22(1 \mathrm{H}, \mathrm{dd}, J=7.6 \mathrm{~Hz}, 1.2$ $\mathrm{Hz}), 9.43(1 \mathrm{H}, \mathrm{d}, J=7.2 \mathrm{~Hz}) .{ }^{13} \mathrm{C} \mathrm{NMR}\left(100 \mathrm{MHz}, \mathrm{CDCl}_{3}\right)$ : $\delta 14.09,21.54,63.31,128.29,132.28,132.77,134.35,137.96$, $138.27,138.70,143.83,166.84,169.52,175.85 . \mathrm{IR}(\mathrm{KBr}): v 2990$, $1634,1573,1373,1311,1005,785$ and $733 \mathrm{~cm}^{-1}$. Anal. Calc. for $\mathrm{C}_{16} \mathrm{H}_{16} \mathrm{BiIO}_{2}$ : C, 33.35; H, 2.80. Found: C, 33.32; H, 3.03.

\section{Results and Discussion}

Initially, we tried the one-pot synthesis of 10 a by the zincation of ethyl 2-iodobenzoate. The arylzinc was prepared by using the method reported by Takagi and coworkers [20], who treated iodoarenes containing an electron-withdrawing substituent, such as a methoxycarbonyl or an acetyl substituent, at the ortho position in the presence of zinc powder under ultrasonication at $30^{\circ} \mathrm{C}$.

When a mixture obtained by sonicating ethyl 2iodobenzoate with zinc powder (1 equiv) at $25^{\circ} \mathrm{C}$ in $\mathrm{DMF}$ was allowed to react with $\mathrm{TolBiCl}_{2}$ (1 equiv), 10a was obtained in only $4 \%$ yield (Table 1, Entry 1 ). The poor yield was attributed to the incomplete conversion of the starting iodoarene to the arylzinc. The yield of 10a was increased by increasing the equivalents of zinc powder and $\mathrm{TolBiCl}_{2}$ (Entries 2 and 3). Furthermore, an increase in the temperature from 25 to $48^{\circ} \mathrm{C}$ during the sonication accelerated the zincation reaction (Entries 4-9). The reaction mixture turned dark yellow during the zincation, which was a good indicator for the completion of the reaction. The yield of 10a was sensitive to the zinc powder loading and the best result was obtained when 4 equiv zinc powder and 2 equiv $\mathrm{TolBiCl}_{2}$ were used (Entry 7 ). Higher zinc powder or $\mathrm{TolBiCl}_{2}$ loadings decreased the yield of 10a (Entries 8 and 9).

Encouraged by the success of the one-pot synthesis of 10a, we performed the one-pot syntheses of $\mathbf{2 a}$ and $\mathbf{5 a}$, which have an acetophenone scaffold, using the reaction conditions used in the synthesis of 10a (Table 1, Entry 7). After the zincation reaction mixtures had turned dark yellow, the arylzinc was allowed to react with $\mathrm{TolBiCl}_{2}$, followed by quenching with a saturated aqueous solution of $\mathrm{NaI}$ to give $\mathbf{2 a}$ and $\mathbf{5 a}$ in $35 \%$ and $28 \%$ yields, respectively, despite the presence of acidic acetyl protons (Table 2, Entries 1 and 2). We have previously reported that the synthesis of $5 \mathbf{a}$ from the corresponding silyl enol ether by conventional directed lithiation failed (Scheme 1) [14]. We explained the failure by the presence of the fluoro substituent, which can act as a directing group. The success in obtaining 5 a demonstrates the usefulness of the zincation method.

Furthermore, we used this method to synthesize 6a-9a, which have a formyl substituent (Entries 3-6). We have previously reported the synthesis of 6 by the directed ortholithiation of lithium $\alpha$-amino alkoxide (Scheme 4) [13]. This method required excess $\mathrm{BuLi}$, which often caused the loss of $\mathrm{Ar}_{2} \mathrm{BiCl}$ or decomposition of the product by overreaction with unreacted BuLi. In addition, the lithium alkoxide moiety could form an undesired bismuth alkoxide by reacting with $\mathrm{Ar}_{2} \mathrm{BiCl}$. Hence, the present zincation overcomes these drawbacks. In particular, 7a, 8a, and 9a were obtained in acceptable yields by the zincation; if conventional directed lithiation was used, the fluoro and methoxy substituents in $7 \mathbf{a}$ and $\mathbf{8 a}$, respectively, would act as directing groups and the thienyl ring proton $\alpha$ to the sulfur atom in $9 \mathbf{a}$ would undergo undesired lithiation. 
TABLE 1: Optimization of the reaction conditions for the synthesis of 10a.

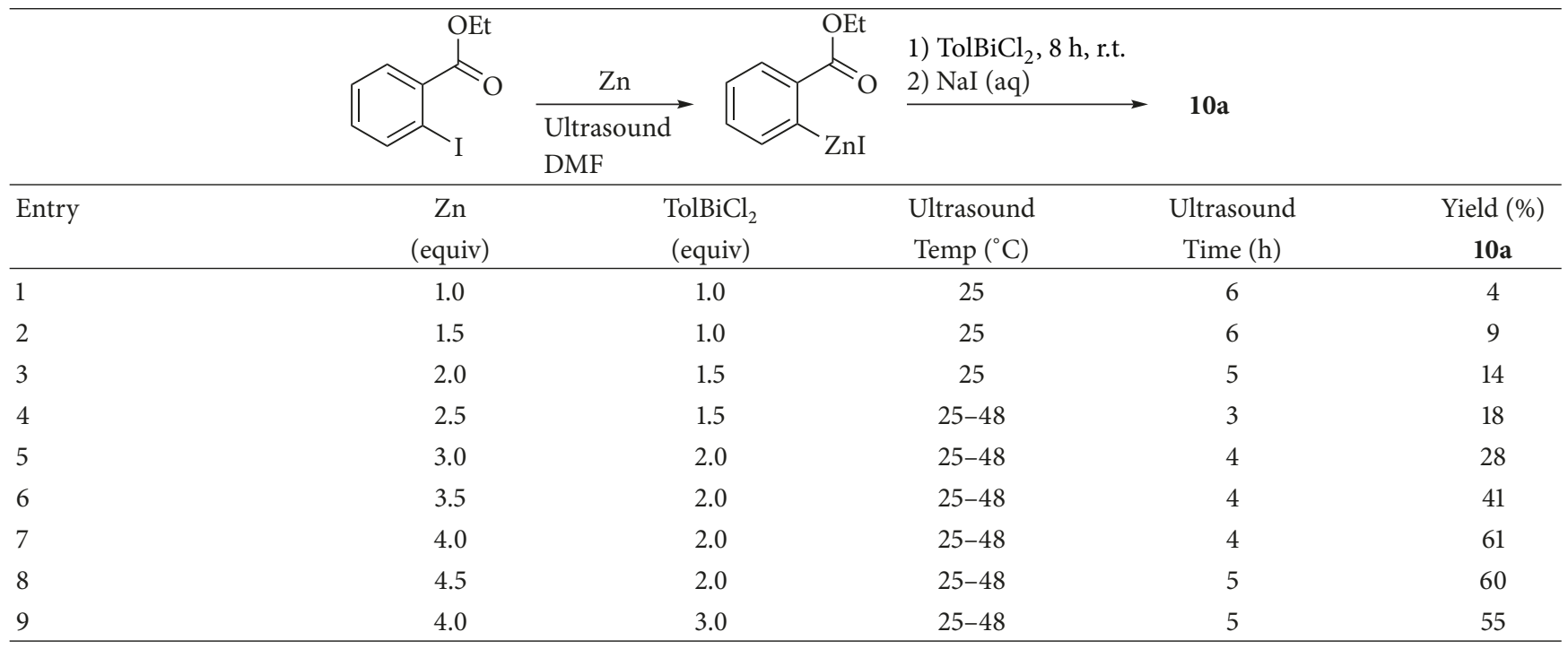

TABLE 2: Synthesis of iodobismuthanes.

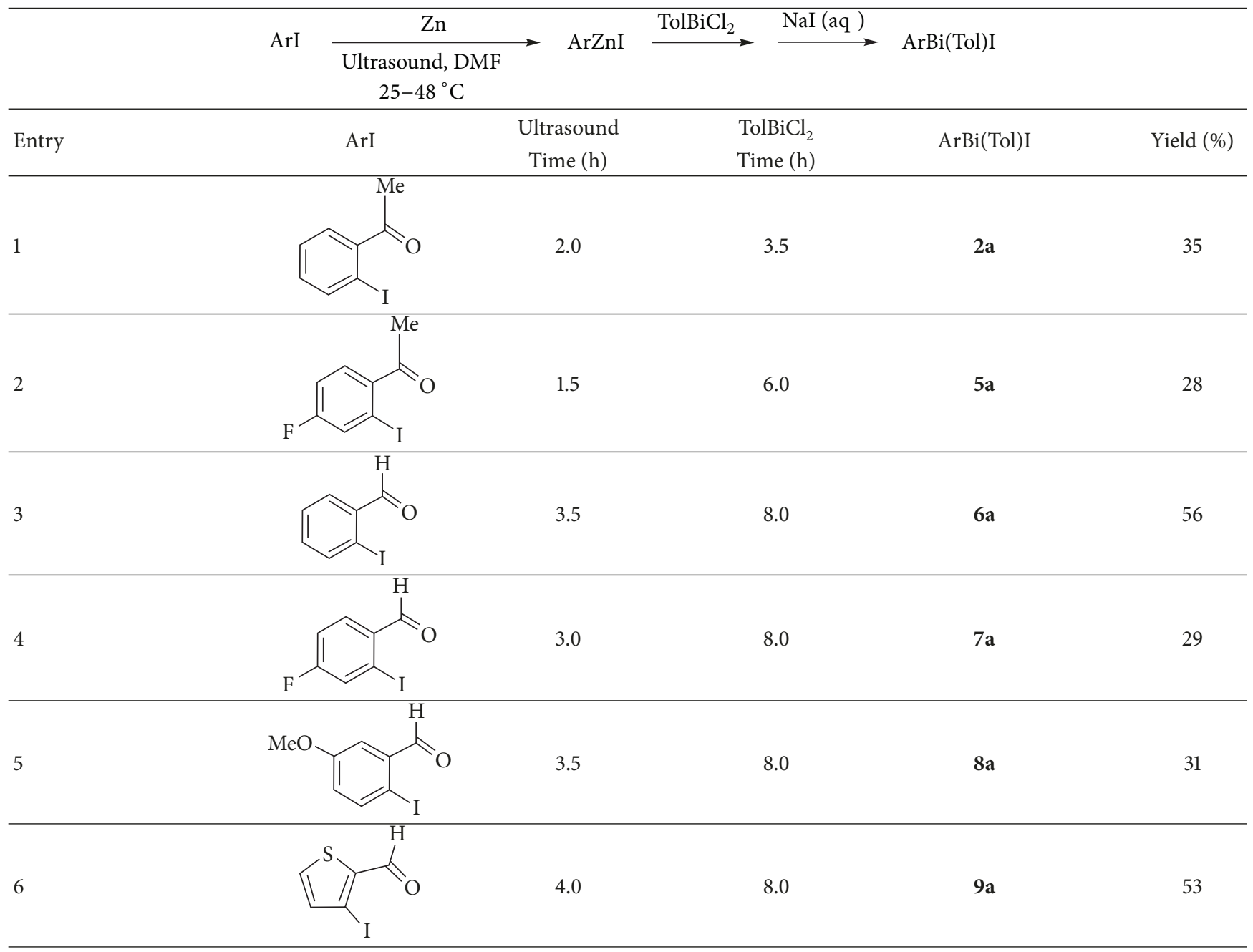


The molecular structure of $2(\mathrm{Ar}=\mathrm{Tol}, \mathrm{X}=\mathrm{Br})$ has been characterized by $\mathrm{X}$-ray structure analysis and ${ }^{13} \mathrm{C}$ NMR and IR spectra, which reveals the formation of a hypervalent $\mathrm{O}-\mathrm{Bi}-\mathrm{Br}$ bond by the intramolecular coordination of the carbonyl group with the bismuth atom [13]. The hypervalent bond formation was also detected in the ${ }^{1} \mathrm{H}$ NMR spectra. The ${ }^{1} \mathrm{H}$ NMR spectrum of $\mathbf{2 a}$ in $\mathrm{CDCl}_{3}$ shows anisotropic deshielding $(\delta 9.41 \mathrm{ppm})$ of the ortho proton adjacent to the bismuth atom in the arylcarbonyl scaffold because of its close proximity to the electronegative iodine atom owing to the hypervalent $\mathrm{O}-\mathrm{Bi}-\mathrm{I}$ bond formation [14]. Compound 10a showed a similar deshielding of the ortho proton signal at $\delta 9.43 \mathrm{ppm}$ in $\mathrm{CDCl}_{3}$, which is consistent with hypervalent bond formation. In contrast, no large deshielding of the aromatic proton was observed in the thienyl ring proton of 9a. This may be attributed to the signal for the $\alpha$-proton of the thienyl ring being shifted downfield because of the effect of the sulfur atom. As a result, the signal due to the $\beta$-proton is apparently not affected by anisotropic deshielding by the iodine atom.

\section{Conclusions}

Hypervalent iodobismuthanes bearing a carbonyl group were synthesized easily with a one-pot reaction using arylzinc reagents. The zinc reagents tolerated carbonyl group, acetyl protons, and ring protons adjacent to fluoro, methoxy, and sulfur functional groups. This indicates that the zincation reaction may be suitable for synthesizing a wide range of hypervalent antifungal bismuth(III) compounds with various molecular scaffolds.

\section{Data Availability}

The ${ }^{1} \mathrm{H}$ and ${ }^{13} \mathrm{C}$ NMR spectral data used to support the findings of this study are included within the supplementary information file.

\section{Conflicts of Interest}

The authors declare that there are no conflicts of interest regarding the publication of this paper.

\section{Acknowledgments}

We are grateful to the Center of Instrumental Analysis, Yamaguchi University and the Tokiwa Instrumentation Analysis Center, Yamaguchi University. This work was supported by JSPS KAKENHI Grant Number 16K05697 to Toshihiro Murafuji.

\section{Supplementary Materials}

See Figures S1-S5 [the ${ }^{1} \mathrm{H}$ NMR spectra of $o$ carbonyl iodoarenes] and Figures S6-S19 [the ${ }^{1} \mathrm{H}$ and ${ }^{13} \mathrm{C}$ NMR spectra of compounds $\mathbf{2 a}$ and $\left.\mathbf{5 a}-\mathbf{1 0 a}\right]$. (Supplementary Materials)

\section{References}

[1] X. Chen, Y. Yamamoto, and K.-Y. Akiba, "Hypervalent tetracoordinate organobismuth compounds (10-Bi-4)," Heteroatom Chemistry, vol. 6, no. 4, pp. 293-303, 1995.

[2] K. Ohkata, S. Takemoto, M. Ohnishi, and K.-Y. Akiba, "Synthesis and chemical behaviors of 12-substituted dibenz $[\mathrm{c}, \mathrm{f}][1,5]$ azastibocine and dibenz $[\mathrm{c}, \mathrm{f}][1,5]$ azabismocine derivatives: Evidences of 10-Pn-4 type hypervalent interaction," Tetrahedron Letters, vol. 30, no. 36, pp. 4841-4844, 1989.

[3] C. I. Raţ, C. Silvestru, and H. J. Breunig, "Hypervalent organoantimony and -bismuth compounds with pendant arm ligands," Coordination Chemistry Reviews, vol. 257, no. 5-6, pp. 818-879, 2013.

[4] S. Shimada, "Recent advances in the synthesis and application of bismuth-containing heterocyclic compounds," Current Organic Chemistry, vol. 15, no. 5, pp. 601-620, 2011.

[5] C. Silvestru, H. J. Breunig, and H. Althaus, "Structural chemistry of bismuth compounds. I. Organobismuth derivatives," Chemical Reviews, vol. 99, no. 11, pp. 3277-3327, 1999.

[6] A. M. Toma, A. Pop, A. Silvestru, T. Rüffer, H. Lang, and M. Mehring, "Bismuth $\cdots \pi$ arene versus bismuth $\cdots$ halide coordination in heterocyclic diorganobismuth(III) compounds with transannular $\mathrm{N} \longrightarrow \mathrm{Bi}$ interaction," Dalton Transactions, vol. 46, no. 12, pp. 3953-3962, 2017.

[7] Y.-P. Liu, J. Lei, L.-W. Tang et al., "Studies on the cytotoxicity and anticancer performance of heterocyclic hypervalent organobismuth(III) compounds," European Journal of Medicinal Chemistry, vol. 139, pp. 826-835, 2017.

[8] M. Olaru, M. G. Nema, A. Soran, H. J. Breunig, and C. Silvestru, "Mixed triorganobismuthines $\mathrm{RAr}_{2} \mathrm{Bi}\left[\mathrm{Ar}=\mathrm{C}_{6} \mathrm{~F}_{5}, 2,4,6\right.$ $\left(\mathrm{C}_{6} \mathrm{~F}_{5}\right)_{3} \mathrm{C}_{6} \mathrm{H}_{2}$ ] and hypervalent racemic Bi-chiral diorganobismuth(III) bromides $\mathrm{RArBiBr}\left(\mathrm{Ar}=\mathrm{C}_{6} \mathrm{~F}_{5}, \mathrm{Mes}, \mathrm{Ph}\right)$ with the ligand $\mathrm{R}=2-\left(\mathrm{Me}_{2} \mathrm{NCH}_{2}\right) \mathrm{C}_{6} \mathrm{H}_{4}$. Influences of the organic substituent," Dalton Transactions, vol. 45, no. 23, pp. 9419-9428, 2016.

[9] X. Zhang, S. Yin, R. Qiu et al., "Synthesis and structure of an air-stable hypervalent organobismuth (III) perfluorooctanesulfonate and its use as high-efficiency catalyst for Mannich-type reactions in water," Journal of Organometallic Chemistry, vol. 694, no. 22, pp. 3559-3564, 2009.

[10] S.-F. Yin and S. Shimada, "Synthesis and structure of bismuth compounds bearing a sulfur-bridged bis(phenolato) ligand and their catalytic application to the solvent-free synthesis of propylene carbonate from $\mathrm{CO}_{2}$ and propylene oxide," Chemical Communications, no. 9, pp. 1136-1138, 2009.

[11] Y. Yamamoto, X. Chen, S. Kojima et al., "Experimental investigation on Edge inversion at trivalent bismuth and antimony: Great acceleration by intra- and intermolecular nucleophilic coordination," Journal of the American Chemical Society, vol. 117, no. 14, pp. 3922-3932, 1995.

[12] Y. Matano, Y. Aratani, T. Miyamatsu et al., "Water-soluble non-ionic triarylbismuthanes. First synthesis and properties," Journal of the Chemical Society, Perkin Transactions 1, no. 16, pp. 2511-2518, 1998.

[13] T. Murafuji, T. Mutoh, K. Satoh, K. Tsunenari, N. Azuma, and H. Suzuki, "Hypervalent bond formation in halogeno(2acylphenyl)bismuthanes," Organometallics, vol. 14, no. 8, pp. 3848-3854, 1995.

[14] T. Murafuji, M. Tomura, K. Ishiguro, and I. Miyakawa, "Activity of antifungal organobismuth(III) compounds derived from alkyl aryl ketones against $S$. cerevisiae: Comparison with a 
heterocyclic bismuth scaffold consisting of a diphenyl sulfone," Molecules, vol. 19, no. 8, pp. 11077-11095, 2014.

[15] A. F. M. Hafizur Rahman, T. Murafuji, K. Yamashita et al., "Synthesis and antifungal activities of pyridine bioisosteres of a bismuth heterocycle derived from diphenyl sulfone," Heterocycles, vol. 96, no. 6, pp. 1037-1052, 2018.

[16] T. Murafuji, K. Nishio, M. Nagasue, A. Tanabe, M. Aono, and Y. Sugihara, "Synthesis of triarylbismuthanes fully substituted with arenes, each bearing a $\pi$-accepting substituent," Synthesis, no. 9, pp. 1208-1210, 2000.

[17] M. Urano, S. Wada, and H. Suzuki, "A novel dry route to orthofunctionalized triarylbismuthanes that are difficult to access by conventional wet routes," Chemical Communications, vol. 3, no. 10, pp. 1202-1203, 2003.

[18] V. Stavila, J. H. Thurston, D. Prieto-Centurión, and K. H. Whitmire, "A new methodology for synthesis of aryl bismuth compounds: Arylation of bismuth(III) carboxylates by sodium tetraarylborate salts," Organometallics, vol. 26, no. 27, pp. 68646866, 2007.

[19] K. Urgin, C. Aubé, C. Pichon et al., "Advanced preparation of functionalized triarylbismuths and triheteroaryl-bismuths: New scope and alternatives," Tetrahedron Letters, vol. 53, no. 15, pp. 1894-1896, 2012.

[20] K. Takagi, "Ultrasound-promoted synthesis of arylzinc compounds using zinc powder and their application to palladium(0)-catalyzed synthesis of multifunctional biaryls," Chemistry Letters, vol. 22, no. 3, pp. 469-472, 1993.

[21] H. Takahashi, S. Inagaki, Y. Nishihara, T. Shibata, and K. Takagi, "Novel Rh catalysis in cross-coupling between alkyl halides and arylzinc compounds possessing ortho- $\mathrm{COX}\left(\mathrm{X}=\mathrm{OR}, \mathrm{NMe}_{2}\right.$, or Ph) groups," Organic Letters, vol. 8, no. 14, pp. 3037-3040, 2006.

[22] A. Krasovskiy, V. Malakhov, A. Gavryushin, and P. Knochel, "Efficient synthesis of functionalized organozinc compounds by the direct insertion of zinc into organic iodides and bromides," Angewandte Chemie International Edition, vol. 45, no. 36, pp. 6040-6044, 2006.

[23] A. Klapars and S. L. Buchwald, "Copper-catalyzed halogen exchange in aryl halides: An aromatic Finkelstein reaction," Journal of the American Chemical Society, vol. 124, no. 50, pp. 14844-14845, 2002. 

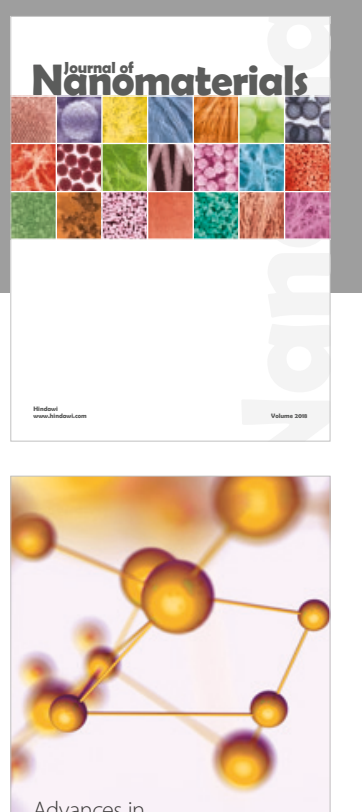

Physical Chemistry
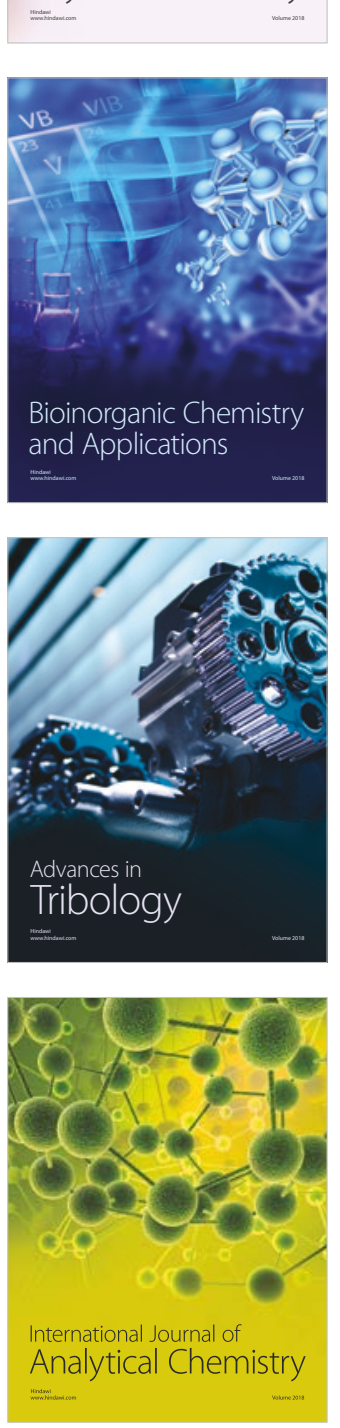

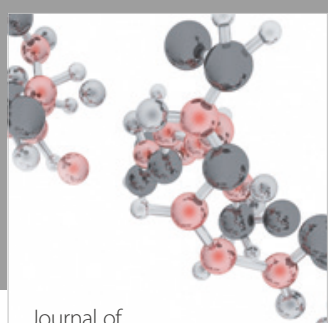

Analytical Methods

in Chemistry

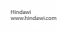

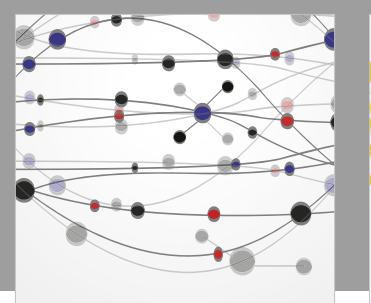

The Scientific World Journal

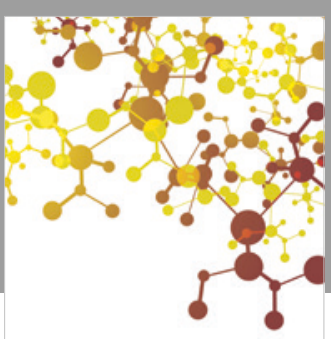

Journal of

Applied Chemistry
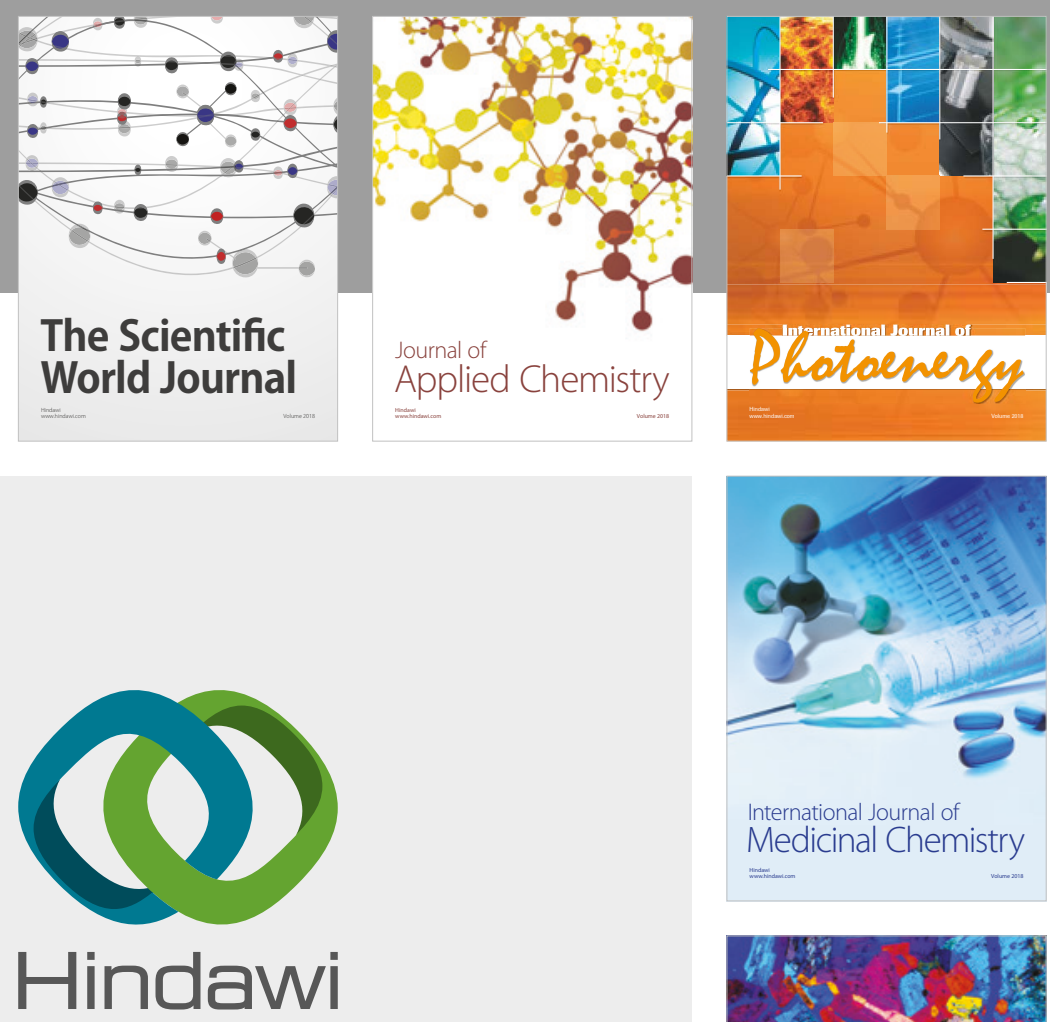

Submit your manuscripts at

www.hindawi.com
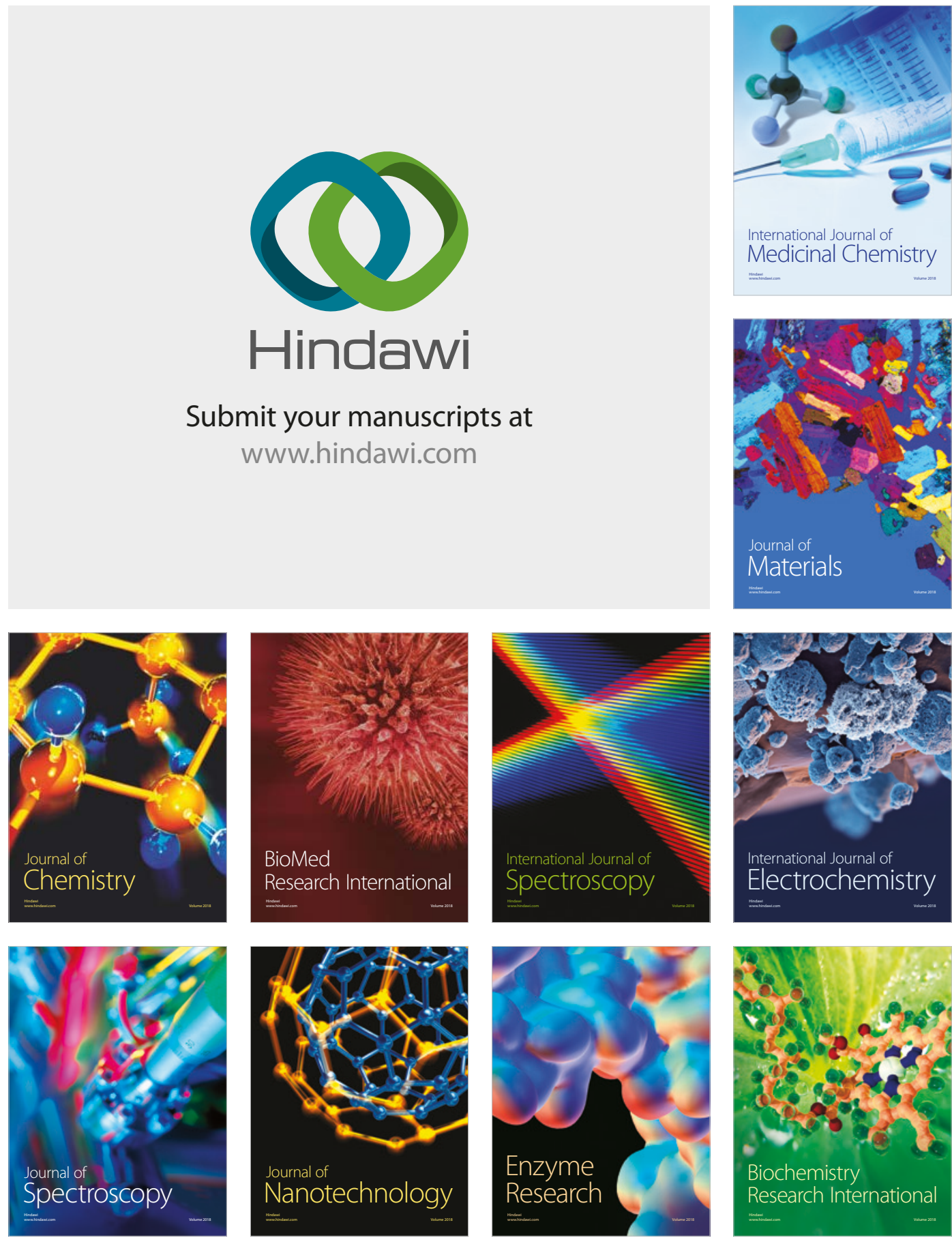
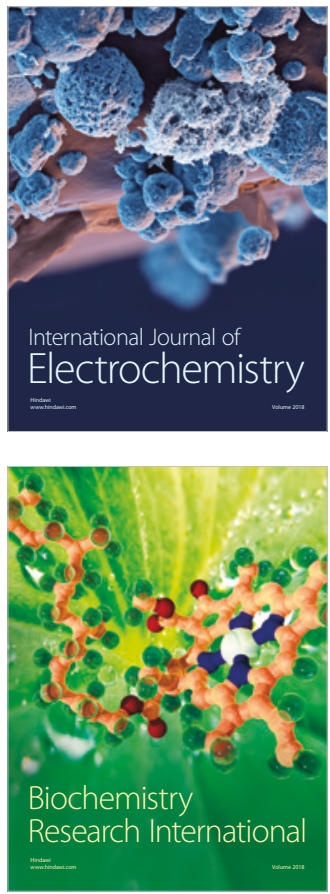